\title{
CONTENTS
}

Vot. XIV. No. 4 .

PAGE

Fronlispiece: Class on Applied Helminthology. London, 1936.

1. Bhalerao, G. D. Studies on the Helminths of India,

$\begin{array}{llllllll}\text { Trematoda II. } & \ldots & \ldots & \ldots & \ldots & \ldots & \ldots & 181-206\end{array}$

2. Bhalerao, G. D. Studies on the Helminths of India,

$\begin{array}{lllllll}\text { Trematoda III. } & \ldots & \ldots & \ldots & \ldots & \ldots & \ldots \\ 207-228\end{array}$

3. Clapham, P. A. Preliminary Observations on the

Infectivity of Ascaris lumbricoides to Swine $\quad . . \quad$... 229-232

4. Johnson, L. R. A note on the occurrence of Anguillulina

dipsaci (Kühn, 1858) on certain weeds, including a new

$\begin{array}{llllllll}\text { host record } & \ldots & \ldots & \ldots & \ldots & \ldots & \ldots & 233-235\end{array}$

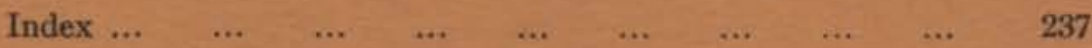

\section{Publications of the}

\section{Institute of Agricultural Parasitology}

(LONDON SCHOOL OF HYGIENE AND TROPICAL MEDICINE)

JOURNAL OF HELMINTHOLOGY. Edited by R. T. LEIPER, M.D., D.Sc., F.R.S.

Issued quarterly, or more frequently as occasion demands, for the publication of original communications by the Staff and Associated Workers of the Institute.

Subscription Price 25/- net a volume, post free. Volumes I to XIII bound in cloth, price $30 /-$ net each, post free. 